\title{
Hubungan Kualitas Produk Wisata dan Peluang Pasar dengan Kepuasan Pelanggan di Wastu Wisata Tri Susilowati ${ }^{1}$, Sri Wastuti ${ }^{2}$ \\ Sekolah Tinggi Penerbangan AVIASI, Jakarta, Indonesia e-mail: susilowati_aviasi@yahoo.co.id, wastuti.zahra@yahoo.co.id
}

\begin{abstract}
This research have purpose to know the relationship between product quality and market opportunities with customer satisfaction in Wastu Wisata. The type or research used quantitative research methods and descriptive methods. Sample of 30 respondents who is the customer Wastu Wisata in the form of suspension refers to scala liekert. Research results show that product quality variables have a significant relationship with customer satisfaction, market opportunity variables with customer satisfaction there is a positive and significant relationship. Many tourism product/ services are currently being offered online, Wastu Wisata product offers the best and ceapest travel packaged attractively. Wastu Wisata ensures to always increase market opportunities in marketing tourism product and efforts to invite customers to prioritized in efforts to use tourism products by providing satisfying product with due respect Wastu Wisata always to increase quality products and market opportunities so that customers feel to be king.
\end{abstract}

Key Words: Product Quality, Market Opportunities, Customer Satisfaction 


\begin{tabular}{|l} 
ABSTRAK \\
Penelitian ini bertujuan untuk mengetahui hubungan kualitas produk dan peluang pasar \\
dengan kepuasan pelanggan di Wastu Wisata. Jenis penelitian yang digunakan adalah \\
metode penelitian kuantitatif dan metode deskriptif. Sampel sebanyak 30 responden yang \\
merupakan pelanggan dari Wastu Wisata dalam bentuk skorsing mengacu pada Scala \\
Liekert. Hasil penelitian menunjukkan bahwa variable kualitas produk ada hubungan dan \\
signifikan dengan kepuasan pelanggan; variable peluang pasar dengan kepuasan pelanggan \\
ada hubungan yang positif dan signifikan. Wastu Wisata harus terus memperhatikan kualitas \\
produk maupun peluang pasar yang ditawarkan dalam upaya meningkatkan kepuasan \\
pelanggan. Dimana produk wisata saat ini banyak penawaran diberbagai online penawaran \\
produk Wastu Wisata harus lebih digiatkan dan paket perjalanan dikemas secara menarik. \\
Wastu Wisata harus senantiasa meningkatkan peluang pasar dalam memasarkan produk \\
wisata dan upaya mengajak para pelanggan untuk menggunakan produk wisata dari Wastu \\
Wisata. Dalam hal ini kepuasan pelanggan harus diprioritaskan dalam upaya penggunaan \\
produk wisata dengan memberikan produk yang memuaskan. Dengan demikian, Wastu \\
Wisata terus meningkatkan kualitas produk dan peluang pasar agar para pelanggan merasa \\
puas dan menjadi raja.
\end{tabular}




\section{PENDAHULUAN}

Mendirikan bisnis travel tidak semudah membalikkan telapak tangan, dimana pada saat ini bisnis travel menjamur dengan munculnya penawaran online. Banyaknya pesaing lewat aplikasi online membuat bisnis travel banyak yang berguguran. Bisnis travel sesungguhnya peluang yang sangat menjanjikan dimana konsumen banyak menggunakan jasa travel untuk melakukan perjalanan.

Tingginya popularitas penawaran paket wisata online sempat memunculkan layanan-layanan serupa lainnya yang mencoba peruntungan. Meski tak sedikit yang akhirnya tumbang, hal itu tak menyurutkan layanan penyedia jasa wisata online terbaru yang siap menantang, yang sama dengan layanan lainnya yang sudah terlebih dahulu beredar. Contoh: Traveloka, Tiket.Com dan Mister Aladin, dari contoh travel online di atas dapat kita simpulkan bahwa jasa travel online sudah banyak pebisnis yang berhasil untuk bersaing. Keberhasilan dalam usaha jasa travel, para penyelenggara dituntut memahami karakteristik industri jasa, dengan mengelola usaha dengan cermat dan inovatif.

Dengan adanya jasa travel di Wastu Wisata konsumen bisa mengunjungi berbagai macam daerah wisata atau negara dengan penawaran yang beragam macam wisata. Peningkatan jumlah tempat wisata sampai saat ini dan penetapan sebagai Kawasan Strategis Pariwisata Nasional menjadi potensi peningkatan Pendapatan Asli Daerah (PAD) dari sektor pariwisata sehingga menjadi sektor unggulan di setiap daerah masing-masing, dalam hal ini Pemerintah sangat mendukung kemajuan daerah dalam pengembangan pariwisata karena dengan adanya wisata maka pendapatan daerah meningkat.

Wastu Wisata menawarkan berbagai macam paket wisata, baik berupa layanan konsultasi perjalanan maupun penyedia sarana prasarana perjalanan, Wastu Wisata memenuhi semua kegiatan penyedia perjalanan dan perencanaan jadwal dalam menyiapkan fasilitas perjalanan untuk ditawarkan kepada pengguna jasa/konsumen. Dengan kehadiran pelayanan lewat online dari traveloka dan tiket.com, Wastu Wisata yang merupakan jasa travel yang mengelola paket wisata, saat ini sepi pelanggan yang menggunakan jasa Wastu Wisata, data dapat terlihat dalam tabel pelanggan jasa Wastu Wisata setiap tahunnya. 
Tabel -1 Data Pengguna Paket Wisata Lima Tahun Terakhir (2012-2016)

\begin{tabular}{|c|c|c|c|c|}
\hline Tahun & Dom. & Intern. & $\begin{array}{c}\text { Pembelian } \\
\text { Tiket Saja }\end{array}$ & $\begin{array}{c}\text { Jumlah } \\
\text { Pengguna }\end{array}$ \\
\hline 2012 & 110 & 20 & 45 & 175 \\
\hline 2013 & 170 & 105 & 40 & 315 \\
\hline 2014 & 208 & 54 & 19 & 280 \\
\hline 2015 & 70 & 220 & 20 & 310 \\
\hline 2016 & - & - & 57 & 57 \\
\hline
\end{tabular}

Sumber: Data Wastu Wisata

\section{Landasan Teori dan Metodologi Penelitian}

Untuk mencapai target penjualan paket perjalanan dibutuhkan suatu perencanaan yang matang baik dalam menawarkan paket perjalanan dikemas secara menarik. Sebagai seorang petugas (tour planner) harus menguasai beberapa aspek yang berkaitan dengan wisata, antara lain:

a) Daya tarik wisata yang memiliki sifat yang unik, asli, dan lokal sebagai pendorong seseorang melakukan kegiatan wisata;

b) Adanya kejadian-kejadian langka, misalkan ngaben di Bali, pemakaman raja di Tanah Toraja, gerhana matahari, dan lain-lain;

c) Ketersediaan sarana pendukung perjalanan yang memenuhi syarat dan dapat menimbulkan kepuasan wisatawan, antara lain transportasi, akomodasi, makanan dan minuman, hiburan dan lain-lain yang diperlukan.
Komponen-komponen tersebut dikemas dalam paket wisata yang meliputi:

a) Jasa angkutan baik udara, laut maupun darat,

b) Jasa penginapan,

c) Jasa penyajian makanan dan minuman,

d) Jasa rekreasi, seni budaya berupa tiket masuk,

e) Jasa pemandu, dan

f) Jasa produk-produk lain yang diperlukan

Keberhasilan suatu usaha dilihat dari beberapa faktor-faktor pendukung, di antaranya :

1) Faktor manusia

2) Faktor keuangan

3) Faktor organisasi

4) Faktor mengatur usaha

5) Faktor pemasaran

Menurut W. Keith Schilit, ada 8 hal yang membuat usaha atau bisnis meraih kesuksesan atau keberhasilan, yaitu :

1) Peluang pasar yang baik.

2) Keunggulan persaingan.

3) Kualitas barang/jasa.

4) Inovasi yang berproses.

5) Dasar budaya perusahaan.

6) Menghargai pelanggan dan pegawai.

7) Manajemen yang berkualitas. 
8) Dukungan modal yang kuat.

Tanpa mengabaikan faktor-faktor lainnya, tampaknya yang paling kuat pengaruhnya ialah produk Wastu Wisata kalah dengan penawaran travel online, sehingga terjadi persaingan frontal (head on) yang tidak seimbang. Untuk menghindari kondisi itu, perlu mengambil strategi diferensiasi produk.

Apabila kecendrungan pelanggan tidak ada maka jumlah pelanggan tidak kunjung meningkat untuk seterusnya, perkembangan Wastu Wisata disebut stagnan. Konsekuensinya kemungkinan besar Wastu Wisata akan menutup paket wisata yang tidak/kurang diminati.

Salah satu dari faktor tersebut di atas yang dijadikan sebagai ujung tombak dalam memperkenalkan dan mendistribusikan paket wisata kepada konsumen adalah bidang pemasaran. Bidang inilah yang bertugas agar produk paket wisata dapat terjual dengan menyakinkan kepada pelanggan. Banyak indikator - indikator yang mempengaruhinya, seperti peluang pasar, dan kualitas barang atau jasa.

\section{Landasan Teori}

\section{a. Produk}

Produk memiliki arti penting bagi perusahaan karena tanpa adanya produk, perusahaan tidak akan dapat melakukan apapun dari usahanya. Pembeli akan membeli produk kalau merasa cocok, karena itu produk harus disesuaikan dengan keinginan ataupun kebutuhan pembeli agar pemasaran produk berhasil. Sedangkan menurut Kotler (2005:84) Produk adalah segala sesuatu yang dapat ditawarkan ke pasar untuk mendapatkan perhatian, dibeli, digunakan, atau dikonsumsi yang dapat memuaskan keinginan atau kebutuhan".

Menurut W.J. Stanton dalam buku DR. Buchari Alma (2000:98) mengemukakan bahwa, "Produk ialah seperangkat atribut baik berwujud maupun tidak berwujud, termasuk didalamnya masalah warna, harga, nama baik pabrik, nama baik toko yang menjual (pengecer), dan pelayanan pabrik serta pelayanan pengecer, yang diterima oleh pembeli guna memuaskan keinginannya”.

\section{b. Produk Wisata/Paket Wisata}

Paket wisata merupakan produk yang disediakan oleh jasa travel, jasa travel adalah suatu perusahaan yang bergerak dalam bidang usaha yang berhubungan dengan perjalanan baik konsultasi perjalanan, maupun penyedia sarana 
prasarana perjalanan, dengan demikian bahwa jasa travel merupakan biro perjalanan yang menyediakan akomodasi perjalanan yang disebut paket wisata.

Pengertian paket wisata menurut Kep.Men.Parpostel No. KM96/HK.103/MPPT-87 adalah sebagai rangkaian dari perjalanan wisata yang tersusun lengkap disertai harga dan persyaratan tertentu, sedangkan menurut A.J. Mulyadi (2009:131) Paket wisata juga dapat diartikan sebagai suatu perjalanan wisata dengan beberapa tujuan wisata yang tersusun dari berbagai fasilitas jasa perjalanan tertentu dan terprogram dalam susunan acaranya dan dipasarkan kepada masyarakat dengan harga yang telah ditetapkan.

MenurutSoetomo (1994:25) yang di dasarkan pada ketentuan WATA (World Association of Travel Agent = Perhimpunan Agen Perjalanan Sedunia), wisata adalah perjalanan keliling selama lebih dari tiga hari, yang diselenggarakan oleh suatu kantor perjalanan di dalam kota dan acaranya antara lain melihat-lihat di berbagai tempat atau kota baik di dalam maupun di luar negeri.

Sebagai produk yang kompleks, produk wisata berbeda dari jenis produk dan jasa yang dihasilkan oleh industri lainnya, terutama industri manufaktur, karena kekhasan dari produk wisata menjadikan produk wisata memerlukan penanganan khusus, berikut ciri-ciri produk wisata menurut A.J. Mulyadi (2009:48-49) yaitu.

1) Tidak dapat disimpan

2) Tidak dapat dipindahkan

3) Produksi dan proses konsumsi terjadi atau berlangsung bersamaan

4) Tidak ada standar ukuran yang pasti atau objektif

5) Pelanggan tidak dapat mencicipi produk itu sebelumnya

6) Pengelolaan produk wisata mengandung risiko besar

Menurut Rigas Doganis keutamaan atau kekhasan produk (features) yang menjadi kunci perbedaan produk antaraperusahaan transportasi udara penyedia jasa transportasi udara dapat digolongkan menjadi lima sebagai berikut.

a) Harga yang ditawarkan perusahaan; yang mencakup harga dan persyaratan yang disertakan.

b) Aspek yang berkaitan dengan jadwal perjalanan; yang mencakup frekuensi layanan, waktu pemberangkatan dan tiba di tujuan, rute, serta layanan langsung atau singgah (stop over). 
c) Aspek yang berkaitan dengan kenyamanan; mencakup yang pertama konfigurasi kabin, tempat duduk, pembagian kelas dan layanan, kamar kecil, termasuk rancangan interior dan warna-warna yang digunakan. Kedua, layanan dan hidangan dalam penerbangan, serta jumlah petugas kabin.

d) Ketersediaan layanan yang mudah dan menyenangkan oleh perusahaan; yang mencakup reservasi, pertiketan, informasi, dan fasilitas.

e) Citra perusahaan dibandingkan dengan perusahaan lain; yang mencakup dampak hasil promosi, logo, pewarnaan, rancangan interior kabin, kantor penjualan, ruang tunggu, serta mutu layanan di darat dan udara.

\section{c. Kualitas Produk}

$$
\text { Menurut Kotler }
$$

"Kualitas produk adalah keseluruhan ciri serta dari suatu produk atau pelayanan pada kemampuan untuk memuaskan kebutuhan yang dinyatakan/ tersirat". Sedangkan menurut Lupiyoadi (2001:158) menyatakan bahwa "Konsumen akan merasa puas bila hasil evaluasi mereka menunjukkan bahwa produk yang mereka gunakan berkualitas “.
Dimensi kualitas produk menurut Kotler dalam buku DR. Buchari Alma (2000:231) yaitu:

$\begin{array}{lrr}\begin{array}{l}\text { Keandalan } \\ \text { kemampuan }\end{array} & \text { (reliability), } \\ \text { memberikan } & \text { jasa } & \text { sesuai } \\ \text { dengan yang } & \text { dijanjikan } \\ \text { terpercaya } & \text { dan } & \text { akurat, } \\ \text { konsisten dan } & \text { kesesuaian } \\ \text { pelayanan. } & & \text { Misalnya } \\ \text { pengawasan } & \text { kualitas } & \text { dan } \\ \text { desain, standar } & \text { karakteristik } \\ \text { operasional kesesuaian dengan }\end{array}$

(2) Daya

tanggap (responsiveness), kemauan dari karyawan dan pengusaha untuk membantu pelanggan dan memberikan jasa dengan cepat serta mendengar dan mengatasi keluhan / complaint yang diajukan konsumen.

(3) Kepastian (assurance), berupa kemampuan karyawan untu menimbulkan keyakinan dan kepercayaan terhadap janji yang telah dikemukakan kepada konsumen.

(4) Empati (Emphaty), kesediaan karyawan dan pengusaha untuk lebih peduli memberikan 
perhatian secara pribadi

kepada pelanggan.

(5) Berwujud (tangible), berupa penampilan fasilitas fisik, peralatan, dan berbagai materi komunikasi.

\section{d. Peluang Pasar}

Indonesia sebagai Negara kepulauan yang terdiri atas 17.508 pulau, memiliki potensi yang sulit dicari tandingannya dengan Negara mana pun di dunia. Aset potensi kepariwisataan Indonesia, tidak saja memenuhi unsur keindahan alam (natural beauty), keaslian (originality), kelangkaan (scarcity) dan keutuhan (wholesomeness), tetapi juga kekayaan seni budaya, flora, dan fauna, ekosistem dan gejala alam. Kesemuanya ini dapat dikombinasikan, diramu, dan kemudian dikemas secara profesional, sehingga menjadi obyek yang memiliki daya tarik yang luar biasa bagi wisatawan nusantara maupu wisatawan mancanegara.

Sektor kepariwisataan memberikan kontribusi yang cukup signifikan di dalam menggerakkan pertumbuhan pembangunan nasional. Secara universal sektor wisata dianggap sangat efektif untuk mendorong pembangunan dalam rangka percepatan pertumbuhan wilayah suatu Negara. Para ahli ekonomi menggunakan istilah pasar untuk merujuk pada suatu kumpulan pembeli dan penjual yang mentransaksikan produk dan kelas produk tertentu; dengan demikian ada pasar perumahan, pasar gandum, dan seterusnya (Philip Kotler dalam Marketing Management Analysis: 11). Dengan demikian, pasar terdiri dari semua pelanggan potensial yang samasama mempunyai kebutuhan atau keinginan yang mungkin ingin dan mampu terlibat dalam pertukaran untuk memuaskan kebutuhan atau keinginan masing-masing pihak.

Dalam percakapan sehari-hari, menurut Philip Kotler orang-orang bisnis menggunakan istilah pasar mencakup beberapa pengelompokkan pelanggan. Mereka berbicara tentang pasar kebutuhan (seperti pasar yang mencari diet), pasar produk (seperti pasar sepatu), pasar demografi (seperti pasar Perancis) atau 
mereka memperluas konsep ini meliputi juga kelompok bukan pelanggan seperti pasar pemilih, pasar tenaga kerja, dan pasar donor.

Aspek ekonomi berkaitan dengan peluang pasar, marketing, produksi, dan perkiraan keuntungan. Berbagai point tersebut sangatlah penting untuk dibahas untuk mengetahui besar perkiraan dari keuntungan yang bisa didapat serta bagaimana pasar menerima produk. Menentukan sistem produksi agar keuntungan bisa lebih maksimal. Sebab ide menarik pun tidak ada arti jika tidak menghasilkan keuntungan.

Analisa peluang pasar ini sangat penting, karena perusahaan perlu mengetahui berapa besarnya peluang yang tersedia dalam memasarkan produknya dan dapat menetapkan apakah pasar cukup besar untuk mendukung produk lain dan masih memberikan laba. Keberhasilan perusahaan dalam mencapai tujuan dan sasaran sangat dipengaruhi oleh kemampuan perusahaan tersebut dalam memasarkan produknya, untuk itu pertumbuhan pasar di masa yang akan datang sangat diperlukan.
Menganalisa peluang pasar juga untuk membuat keputusan apakah perusahaan akan terus menjalankan kegiatannya dengan meningkatkan produktifitasnya atau harus keluar dari pasar.

Pengertian peluang pasar menurut Kotler (1997:72) adalah sebagai berikut: Peluang pasar adalah suatu bidang kebutuhan pembeli dimana perusahaan dapat beroperasi secara menguntungkan. Sedangkan Pearce dan Robinson (2000-230) memberikan pengertian peluang pasar : Pasar adalah situasi penting yang paling menguntungkan dalam lingkungan perusahaan. Analisa peluang pasar merupakan proses riset terhadap faktor-faktor lingkungan ekstern yang mempengaruhi kegiatan usaha perusahaan tersebut. Lingkungan ekstern merupakan kekuatan yang tidak dapat dikendalikan, sehingga perusahaan harus menyesuaikan diri, dan juga menghasilkan ancaman dan peluang. Perusahaan harus berhati-hati dalam menganalisis lingkungannya sehingga dapat menghindari ancaman dan mengambil manfaat dari peluang. 
Untuk meningkatkan volume penjualan dan merebut pangsa pasar yang besar, maka perusahaan harus menggunakan kebijaksanaankebijaksanaan yang tepat untuk memasuki peluang pasar yang ada. Selanjutnya perusahaan harus melihat potensi dari pasar.

Kotler (1997:118) menyatakan bahwa: Potensi pasar adalah batas yang di dekati oleh permintaan ketika pengeluaran pemasaran industri mendekati tak terhingga untuk lingkungan yang telah di tentukan.

Sedangkan menurut Kartajaya (2002-49) memberikan pengertian segmentasi pasar tersebut sebagai berikut: Segmentasi pasar adalah tentang pemetaan (mapping) suatu pasar menjadi beberapa kategori dengan mengumpulkan perilaku yang serupa dari pelanggan ke dalam sebuah segmen.

Dari setiap kelompok konsumen dapat dipilih sebagai suatu pasar sasaran yang akan dicapai dengan menggunakan strategi bauran pemasaran yang tepat. Adapun langkah-langkah yang diperlukan dalam strategi pemasaran dalam bidang pariwisata menurut DR. Buchari Alma (2002:286) sebagai berikut:

1. Tentukan segmen pasar di mana strategi akan diarahkan yaitu:

a. Negara atau daerah yang merupakan pasaan potensial, yang mungkin diharapkan menjadi konsumen

b. Kelas sosial, tingkat pendidikan dan cara hidup masyarakat tertentu.

c. Tingkat penghasilan yang dimiliki masyarakat, setelah dikurangi kebutuhankebutuhan pokok.

d. Anggota masyarakat yang mempunyai waktu luang.

e. Keluarga-keluarga yang tidak banyak mempunyai anak, ataupun khusus ditujukan kepada kelompok anak-anak.

2. Harus diketahui apa yang menjadi perhatian, atau selera dari masyarakat.

3. Perhatikan faktor-faktor yang dapat mendorong permintaan konsumen, seperti fasilitas, 
kemudahan, faktor harga, faktor produk itu sendiri, pelayanan waktu yang tepat dan sebagainya.

4. Perhatikan pula, bahwa ada dua lembaga penting dalam pemasaran industri pariwisata yang perlu diperhatikan yaitu:

a. Perantara, seperti agen perjalanan.

b. Konsumen akhir wisatawan, kaum pedagang, yang senang bepergian, orang yang akan mengadakan konferensi, rapat kerja, dan sebagainya.

\section{e. Kepuasan Pelanggan}

Agar pelanggan tidak meninggalkan produk dan memakai produk kita kembali sebaiknya pihak travel memberikan pelayanan yang terbaik yang disusun secara tetap dan paket wisata dengan biaya yang terjangkau. Menurut DR. Buchari Alma bahwa tujuan pemasaran bukan mencari laba, tetapi memberi kepuasan. Dengan adanya kepuasan akan terjadi pembelian ulang.

Menurut Zeithmal et al. dalam buku DR. Buchari Alma, menyatakan satisfaction adalah respon konsumen yang sudah terpenuhi keinginannya. Ada perkiraan terhadap features barang dan jasa, yang telah memberikan tingkat kesenangan tertentu dan konsumen betul-betul puas.

Agar mendapat sasaran yang diharapkan dari pelanggan berikut ciri-ciri Pelanggan yang puas :
a. Pembelian produk yang berulang-ulang
b. Promosi pelanggan dengan memberitahukan teman
c. Perusahaan menjadi pertimbangan utama

Berdasarkan pengertian di atas bahwa kepuasan pelanggan tidak terlepas dari kualitas produk dan peluang pasar yang digunakan pelanggan. Hal ini mengakibatkan kepuasan pelanggan merupakan salah satu faktor penting untuk memenangkan persaingan.

\section{METODE PENELITIAN}

Penulis akan mengolah data-data primer yang berkaitan dengan kualitas produk dan peluang pasar untuk mengetahui hubungan terhadap kepuasan pelanggan pada paket wisata di Wastu 
Wisata. Adapun metode analisis data yang digunakan adalah penelitian kuantitatif dan deskriptif (Suharsimi Arikunto, 2002 , dan M. Nazir, 2003) :

\section{Metode Deskriptif}

Metode ini digunakan untuk memberikan gambaran atas fakta yang ada secara sistimatis dan akurat serta hubungan antara masalah-masalah diteliti.

\section{Metode Kuantitatif}

Menggunakan data kuantitatif untuk menganalisis kualitas produk dan peluang pasar untuk mengetahui hubungan terhadap kepuasan pelanggan pada paket wisata di Wastu Wisata. Data ini adalah data kualitatif yang diangkakan dalam bentuk skorsing mengacu pada Scala Liekert. Pada skala ini menggunakan hanya item yang secara pasti baik dan secara pasti buruk. Skor responsi responden dijumlahkan dan jumlah ini merupakan total skor, dan total skor inilah ditafsirkan sebagai posisi responden. Data yang terkumpul melalui kuesioner ini diberi nilai dengan menerapkan Skala Liekert 1 sampai dengan 5. Data pernyataan responden yang masuk berdasarkan pilihan jawaban dari 1 sampai 5. Setiap angka menunjukan kategori tingkat persetujuan, angka 1 menyatakan sangat tidak setuju dan angka 5 menyatakan sangat setuju.

Pengukuran penilaiannya adalah sbb:

a. Pilihan jawaban sangat tdk setuju diberi nilai 1

b. Pilihan jawaban tdk setuju diberi nilai 2

c. Pilihan jawaban kurang setuju diberi nilai 3

d. Pilihan jawaban setuju diberi nilai 4

e. Pilihan jawaban sangat setuju diberi nilai 5

Dalam mendiskripsikan hasil penelitian, maka ditentukan lima kelas atau katagori skor. Untuk menentukan katagori ini digunakan rumus sebagai berikut :

$$
\mathrm{I}=\frac{\mathrm{R}}{\mathrm{Jk}}
$$

Dimana :

$$
\begin{aligned}
\mathrm{I}= & \text { Interval } \\
\mathrm{R}= & \text { Jarak pengukuran (kemungkinan } \\
& \text { jumlah skor tertinggi dikurangi } \\
& \text { kemungkinan jumlah skor } \\
& \text { terendah). } \\
\mathrm{Jk}= & \text { Jumlah jarak kelas }
\end{aligned}
$$

Dengan demikian untuk variabel bebas yaitu peluang pasar dan kualitas produk, variabel terikat yaitu kepuasan pelanggan, maka kemungkinan skor 
yang tertinggi adalah 5 (lima) dan kemungkinan skor terendah 1 (satu) serta jumlah jarak kelas adalah 5 (lima), maka interval kelas dapat ditentukan sebagai berikut (Suharsimi Arikunto, 2002) :

$\mathrm{I}=\frac{\mathrm{R}}{\mathrm{Jk}}=\frac{5-1}{5}=0,8$

Berdasarkan interval tersebut, maka dapat ditentukan ukuran atau kategori skor, tabel sebagai berikut :

Tabel-2. Skor dan Tafsirannya

\begin{tabular}{|l|l|}
\hline \multicolumn{1}{|c|}{ Nilai Skor } & \multicolumn{1}{|c|}{ Tafsirannya } \\
\hline Nilai Skor $1 \div<1,8$ & $\begin{array}{l}\text { Kategori Sangat } \\
\text { Rendah }\end{array}$ \\
\hline Nilai Skor $1,8 \div<2,6$ & Kategori Rendah \\
\hline Nilai Skor $2,6 \div<3,4$ & Kategori Cukup \\
\hline Nilai Skor $3,4 \div<4,2$ & Kategori Tinggi \\
\hline Nilai Skor $4,2 \div 5$ & Kategori Sangat Tinggi \\
\hline
\end{tabular}

Sumber : Suharsimi Arikunto

3. Uji Reliabilitas data, Uji Validitas data dilakukan untuk melihat instrument yang digunakan reliable dan data abash / valid. Kemudian baru dilakukan Uji Normalitas data dengan menggunakan data absah/valid, jika data tidak berdistribusi normal maka tidak dapat dilakukan uji Regresi. Uji Reliabilitas dengan rumus Cronbach Alpha dan uji Validitas dengan mengkorelasikan setiap rata-rata skor rekapitusasi setiap butir pertanyaan dengan rata-rata skor variable bersangkutan.
Rumus Cronbach Alpha untuk uji reliabilitas instrument :

$$
\mathrm{r}_{11}=\left[\frac{\mathrm{k}}{\mathrm{k}-1}\right]\left[1 \frac{\Sigma \mathrm{S}_{\mathrm{i}}}{\mathrm{S}_{\mathrm{i}}}\right]
$$

Dimana :

$\mathrm{r}_{11}=$ nilai reliabilitas

$\sum \mathrm{Si}=$ jumlah varians skor tiap-tiap item

$\mathrm{S}_{\mathrm{t}}=$ varians total

$K=$ jumlah item

Rumus Korelasi untuk uji Validitas :

$$
\mathrm{r}=\frac{\mathrm{n} \Sigma \mathrm{X} \mathrm{Y}-(\Sigma \mathrm{X})(\Sigma \mathrm{Y})}{\sqrt{\left[\mathrm{n} \Sigma \mathrm{X}^{2}-(\Sigma \mathrm{X})^{2}\right\}\left\{\mathrm{n} \Sigma \mathrm{Y}^{2}-(\Sigma \mathrm{Y})^{2}\right)}}
$$

dimana :

$\mathrm{r}=$ Korelasi

$\mathrm{n}=$ Jumlah responden

$\mathrm{X}=$ Skor rata-rata hasil rekapitulasi item pertanyaan

$\mathrm{Y}=$ Skor rata-rata hasil rekapitulasi Variabel bersangkutan

Hubungan kualitas produk dengan peluang pasar terhadap kepuasan pelanggan di Wastu Wisata, dapat dikatakan hubungan yang fungsional. Untuk mengetahui hubungan dua variabel independen dengan variabel dependen harus dihitung Korelasi Ganda. Korelasi Ganda bukan merupakan penjumlahan Korelasi Product Moment sederhana antara satu variabel independent dengan variabel dependen melainkan dengan 
rumus tersendiri. Korelasi Ganda (R) merupakan angka yang menunjukan arah dan kuatnya hubungan antara dua variabel independen secara bersama-sama terhadap variabel dependen.

Adapun rumusnya sebagai berikut :

$$
\begin{aligned}
& \text { R. } X_{1} \cdot X_{2} \cdot Y=\sqrt{\frac{r^{2} X_{1} Y+r^{2} X_{2} Y-2 r X_{1} Y \cdot r X_{2} Y \cdot r X_{1} X_{2}}{1-r^{2} X_{1} X_{2}}} \\
& \text { R.X1.X2.Y = Korelasi antara varibel X1 }
\end{aligned}
$$

a. Jika nilai $\mathrm{r}>0$ artinya telah terjadi hubungan yang linier positif, yaitu makin besar nilai variabel $\mathrm{X}$ (independen/bebas), makin besar pula nilai variabel $\mathrm{Y}$ (dependen/terikat) atau sebaliknya.

b. Jika nilai $\mathrm{r}<0$ artinya telah terjadi hubungan yang linier negatif, yaitu makin kecil nilai variabel $X$ (independen), maka makin besar nilai variabel $\mathrm{Y}$ (dependen) atau sebaliknya.

c. Jika nilai $r=0$ artinya tidak ada hubungan sama sekali antara variabel $\mathrm{X}$ (independen) dengan variabel Y (dependen).

d. Jika nilai $\mathrm{r}=1$ atau $\mathrm{r}=-1$ telah terjadi hubungan linier sempurna yaitu garis lurus, sedangkan untuk nilai $\mathrm{r}$ yang makin mengarah ke angka 0 maka garis makin tidak lurus.

e. Pengujiaan $r$ dengan $r$ tabel mengacu pada tingkat signifikan

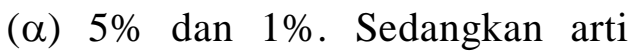
harga $r$ akan dikonsultasikan dengan Tabel 5, interpretasi Nilai $r$ sebagai berikut :

\section{Tabel-3. Interpretasi Koefisien Korelasi}

\begin{tabular}{|c|c|}
\hline $\begin{array}{c}\text { Interval } \\
\text { Koefisien }\end{array}$ & $\begin{array}{c}\text { Tingkat } \\
\text { Hubungan }\end{array}$ \\
\hline $0,00 \mathrm{~s} / \mathrm{d} \pm 0,199$ & Sangat rendah \\
$\pm 0,20 \mathrm{~s} / \mathrm{d} \pm 0,399$ & Rendah \\
$\pm 0,40 \mathrm{~s} / \mathrm{d} \pm 0,599$ & Cukup kuat \\
$\pm 0,60 \mathrm{~s} / \mathrm{d} \pm 0.799$ & Kuat \\
$\pm 0,80 \mathrm{~s} / \mathrm{d} \pm 1,000$ & Sangat kuat \\
\hline
\end{tabular}

Sumber : Suharsimi Arikunto

f. Untuk diketahui apakah korelasi $r$ yang didapat ada artinya perlu diadakan pengujian statistik $t$ dengan rumus sebagai berikut :

$$
\begin{aligned}
& \mathrm{t}=\frac{\mathrm{r} \sqrt{(\mathrm{N}-2)}}{\sqrt{1-\mathrm{r}^{2}}} \\
& \text { dengan } d k=\mathrm{N}-2
\end{aligned}
$$

g. Untuk mengetahui besarnya hubungan antara kualitas produk dan peluang pasar dengan kualitas pelanggan pada paket wisata di Wastu Wisata dihitung dengan 
menghitung Koefisien Determinasi (KD) dengan rumus sebagai berikut:

$\mathrm{KD}=\mathrm{r}^{2} \mathrm{X} 100 \%$

Untuk diketahui apakah korelasi ganda $R$ yang didapat dan ada artinya perlu diadakan pengujian statistik $F$ dengan rumus sebagai berikut:

$$
\mathrm{F}=\frac{\mathrm{R}^{2} / \mathrm{k}}{\left(1-\mathrm{R}^{2}\right) /(\mathrm{n}-\mathrm{k}-1)}
$$

Dimana :

$$
\begin{array}{ll}
\mathrm{R}= & \text { Koefisien Korelasi Ganda } \\
\mathrm{K}= & \text { Jumlah Variabel Independen } \\
\mathrm{N}= & \text { Jumlah anggota sampel }
\end{array}
$$

Jika ternyata perhitungan $\mathrm{F}>\mathrm{F}$ tabel, maka terdapat hubungan yang sangat erat antara dua variabel independen secara bersama-sama dengan variable dependen.

Analisis regresi berganda dilakukan bila hubungan dua variabel berupa hubungan sebab akibat/kausal. Penelitian ini dilakukan untuk mengetahui hubungan kualitas produk dan peluang pasar dengan kepuasan pelanggan pada paket wisata di Wastu Wisata.

Persamaan regresi untuk dua prediktor adalah :

$\mathrm{Y}=\mathrm{a}+\mathrm{b}_{1} \mathrm{X}_{1}+\mathrm{b}_{2} \mathrm{X}_{2}$
Untuk menghitung harga-harga a, b1, b2 dapat menggunakan persamaan berikut :

$\Sigma \mathrm{Y}=\mathrm{an}+\mathrm{b}_{1} \Sigma \mathrm{X}_{1}+\mathrm{b}_{2} \Sigma \mathrm{X}_{2}$

$\Sigma \mathrm{X}_{1} \mathrm{Y}=\mathrm{a} \Sigma \mathrm{X}_{1}+\mathrm{b}_{1} \Sigma \mathrm{X}_{1}+\mathrm{b}_{2} \Sigma \mathrm{X}_{1} \mathrm{X}_{2}$

$\Sigma \mathrm{X}_{2} \mathrm{Y}=\mathrm{a} \Sigma \mathrm{X}_{1}+\mathrm{b}_{1} \Sigma \mathrm{X}_{1}+\mathrm{b}_{2} \Sigma \mathrm{X}_{2^{2}}$

Koefisien determinasi $\left(\mathrm{R}^{2}\right) 2$ prediktor adalah :

Uji signifikansi koefisien korelasi ganda adalah sebagai berikut :

$$
F=\frac{R^{2}(n-m-1)}{M\left(1-R^{2}\right)}
$$

$\mathrm{n}=$ Jumlah responden

$\mathrm{m}=$ Jumlah variabel

\section{Analisa dan Pembahasan}

\section{Analisa Penelitian Uji Validitas}

a. Uji Validitas Kualitas Produk (X) Hasil uji validitas dengan mempergunakan sebanyak 30 responden, dimana menunjukkan bahwa data yang diperoleh adalah valid (lihat Tabel-3), sehingga data yang diperoleh pada penelitian ini layak untuk diuji. Nilai koefisien korelasi tertinggi pada masing-masing item untuk variable kualitas produk $\left(\mathbf{X}_{1}\right)$ adalah 0,805 dan nilai terendah adalah sebesar 0,466. 
Tabel-4. Total Statistics $\left(\mathbf{X}_{1}\right)$

\begin{tabular}{|c|c|c|c|}
\hline Pertanyaan & $\mathbf{r}_{\text {hitung }}$ & $\mathbf{r}_{\text {tabel }}$ & Kesimpulan \\
\hline $\mathrm{X} 1.1$ & .632 & .374 & Valid \\
\hline $\mathrm{X} 1.2$ & .588 & .374 & Valid \\
\hline $\mathrm{X} 1.3$ & .723 & .374 & Valid \\
\hline $\mathrm{X} 1.4$ & .805 & .374 & Valid \\
\hline $\mathrm{X} 1.5$ & .811 & .374 & Valid \\
\hline $\mathrm{X} 1.6$ & .753 & .374 & Valid \\
\hline $\mathrm{X} 1.7$ & .792 & .374 & Valid \\
\hline $\mathrm{X} 1.8$ & .466 & .374 & Valid \\
\hline $\mathrm{X} 1.9$ & .791 & .374 & Valid \\
\hline $\mathrm{X} 1.10$ & .779 & .374 & Valid \\
\hline Sumber : Olahan SPSS, 2016
\end{tabular}

\section{b. Uji Validitas Peluang Pasar $\left(\mathbf{X}_{2}\right)$}

Hasil uji validitas dengan mempergunakan sebanyak 30 responden, dimana menunjukkan bahwa data yang diperoleh terdapat 1 butir (pada no. 1) memiliki nilai $r$ hitung $<r_{\text {tabel }}$ tidak valid) maka butir tersebut nilai dan skornya tidak akan dipergunakan untuk menjadi instrument penelitian (lihat Tabel4), nilai koefisien korelasi tertinggi pada peluang pasar $\left(\mathrm{X}_{2}\right)$ sebesar 0,868 dan nilai terendah sebesar 0,178 .

Tabel-5. Item-Total Statistics $\left(\mathbf{X}_{\mathbf{2}}\right)$

\begin{tabular}{|c|c|c|c|}
\hline Pertanyaan & $\mathbf{r}_{\text {hitung }}$ & $\mathbf{r}_{\text {tabel }}$ & Kesimpulan \\
\hline $\mathrm{X} 2.1$ & .178 & .374 & Tidak valid \\
\hline $\mathrm{X} 2.2$ & .853 & .374 & Valid \\
\hline $\mathrm{X} 2.3$ & .779 & .374 & Valid \\
\hline $\mathrm{X} 2.4$ & .829 & .374 & Valid \\
\hline $\mathrm{X} 2.5$ & .845 & .374 & Valid \\
\hline $\mathrm{X} 2.6$ & .883 & .374 & Valid \\
\hline $\mathrm{X} 2.7$ & .749 & .374 & Valid \\
\hline $\mathrm{X} 2.8$ & .868 & .374 & Valid \\
\hline $\mathrm{X} 2.9$ & .815 & .374 & Valid \\
\hline $\mathrm{X} 2.10$ & .750 & .374 & Valid \\
\hline Sumber : Olahan SPSS, 2016
\end{tabular}

\section{c. Uji Validitas Kualitas Pelanggan} (Y)

Hasil uji validitas dengan mempergunakan sebanyak 30 responden, dimana menunjukkan bahwa data yang diperoleh adalah valid (lihat Tabel-4), sehingga data yang diperoleh pada penelitian ini layak untuk diuji. Nilai koefisien korelasi tertinggi pada masingmasing item untuk koefisien korelasi tertinggi untuk kualitas pelanggan sebesar 0,763 dan nilai terrendah sebesar 0,374. Semua hasil uji validitas menunjukkan angka $\alpha<0,05$ sehingga dinyatakan valid.

Tabel-6. Total Statistic (Y)

\begin{tabular}{|c|c|c|c|}
\hline Pertanyaan & $\mathbf{r}_{\text {hitung }}$ & $\mathbf{r}_{\text {tabel }}$ & Kesimpulan \\
\hline $\mathrm{Y}_{1}$ & .666 & .374 & valid \\
\hline $\mathrm{Y}_{2}$ & .548 & .374 & valid \\
\hline $\mathrm{Y}_{3}$ & .586 & .374 & valid \\
\hline$Y_{4}$ & .763 & .374 & valid \\
\hline $\mathrm{Y}_{5}$ & .505 & .374 & valid \\
\hline $\mathrm{Y}_{6}$ & .635 & .374 & valid \\
\hline$Y_{7}$ & .374 & .374 & valid \\
\hline $\mathrm{Y}_{8}$ & .666 & .374 & valid \\
\hline$Y_{9}$ & .454 & .374 & valid \\
\hline $\mathrm{Y}_{10}$ & .780 & .374 & valid \\
\hline
\end{tabular}




\section{Uji Reliabilitas}

a. Uji Reliabilitas Variabel Kualitas Produk $\left(\mathbf{X}_{1}\right)$

Tabel-7. Scale Statistics

\begin{tabular}{|c|r|r|r|}
\hline Mean & Variance & $\begin{array}{c}\text { Std. } \\
\text { Deviation }\end{array}$ & $\begin{array}{c}\text { N of } \\
\text { Items }\end{array}$ \\
\hline 38.7667 & 36.461 & 6.03829 & 10 \\
\hline
\end{tabular}

Hasil dari perhitungan tabel di atas rata-rata jawaban kuesioner untuk kualitas produk 38,766 dengan varians sebesar 36,46 dan deviasi standar sebesar 6,038 (lihat Tabel-6).

Tabel- 8. Reliability Statistics

\begin{tabular}{|r|r|}
\hline Cronbach's Alpha & N of Items \\
\hline .868 & 10 \\
\hline
\end{tabular}

Reliability statistics di dapat koefisien reliabilitas (cronbach's alpha) sebesar 0,868 lebih besar dari 0,6 sehingga kesimpulan yang diambil adalah masing-masing item pertanyaan adalah reliabilitas.

b. Uji Reliabilitas Variabel Peluang $\operatorname{Pasar}\left(\mathbf{X}_{2}\right)$

Tabel-9. Scale Statistics

\begin{tabular}{|c|r|r|r|}
\hline Mean & Variance & $\begin{array}{c}\text { Std. } \\
\text { Deviation }\end{array}$ & $\begin{array}{c}\text { N of } \\
\text { Items }\end{array}$ \\
\hline 36.166 & 61.10 & 7.817 & 10 \\
\hline
\end{tabular}

Hasil dari perhitungan tabel di atas ratarata jawaban kuesioner untuk peluang pasar 36,166 dengan varians sebesar 61,10 dan deviasi standar sebesar 7,817 (lihat Tabel-8).
Tabel- 10. Reliability Statistics

\begin{tabular}{|l|l|}
\hline Cronbach's Alpha & N of Items \\
\hline .926 & 10 \\
\hline Reliability statistics didapat
\end{tabular}

koefisien reliabilitas (cronbach's alpha) sebesar 0,926 lebih besar dari 0,6 sehingga kesimpulan yang diambil adalah masing-masing item pertanyaan adalah reliabilitas (lihat Tabel-9).

\section{c. Uji Reliabilitas Variabel Kualitas Pelanggan (Y)}

Hasil dari perhitungan rata-rata jawaban kuesioner untuk peluang pasar 40,66 dengan varians sebesar 17,19 dan deviasi standar sebesar 4,146 (lihat Tabel-10).

Tabel-11. Scale Statistics

\begin{tabular}{|c|r|r|r|}
\hline Mean & Variance & $\begin{array}{c}\text { Std. } \\
\text { Deviation }\end{array}$ & $\begin{array}{c}\text { N of } \\
\text { Items }\end{array}$ \\
\hline 40.666 & 17.19 & 4.146 & 10 \\
\hline
\end{tabular}

Reliability statistics didapat koefisien reliabilitas (cronbach's alpha) sebesar 0,763 lebih besar dari 0,6 sehingga kesimpulan yang diambil adalah masing-masing item pertanyaan adalah reliabilitas (lihat Tabel-11).

Tabel- 12. Reliability Statistics

\begin{tabular}{|r|r|}
\hline Cronbach's Alpha & N of Items \\
\hline .763 & 10 \\
\hline
\end{tabular}




\section{Analisis Penelitian}

\section{a. Analisa Koefisien Korelasi}

1) Besar hubungan antara variabel kualitas produk dan variabel kepuasan pelanggan yang dihitung dengan koefisien korelasi adalah 0,238 dengan nilai signifikan sebesar 0,103 .

2) Besar hubungan antara variabel peluang pasar dengan variabel kepuasan pelanggan yang dihitung dengan koefisien korelasi adalah 0,26 dengan nilai signifikan sebesar 0,446.

3) Untuk melihat keeratan hubungan / korelasi antara variabel bebas $\left(X_{1}\right.$ dan $\left.X_{2}\right)$ dengan variabel terikat (Y), maka dengan melihat Tabel-12, dapat diintreprestasikan sebagai berikut berikut:

Untuk kualitas produk hubungan / keeratannya dengan variabel kepuasan pelanggan sangat kuat/korelasi sangat erat $(0,238$ $>0,103)$. Variabel peluang pasar hubungan / keeratannya dengan variabel kepuasan pelanggan rendah / korelasi rendah $(0,26<$ 0,446). Tingkat signifikan koefisien korelasi dua sisi dari output (diukur dari probabilitas) pada tabel korelasi

(Correlations) menghasilkan angka 0.000 (terlihat pada tabel tanda Sig) maka korelasi variabel kualitas produk dan variabel peluang pasar dengan variabel kepuasan pelanggan signifikan karena probabilitas dibawah 0,05 .

Tabel- 13. Correlation

\begin{tabular}{|c|c|c|c|c|}
\hline & & Y & X1 & $\mathrm{X} 2$ \\
\hline $\mathrm{Y}$ & $\begin{array}{l}\text { Pearson } \\
\text { Correlation } \\
\text { Sig. (2- } \\
\text { tailed) } \\
\mathrm{N}\end{array}$ & 30 & $\begin{array}{r}.238 \\
.206 \\
30\end{array}$ & $\begin{array}{r}.026 \\
.892 \\
30\end{array}$ \\
\hline $\mathrm{X} 1$ & $\begin{array}{l}\text { Pearson } \\
\text { Correlation } \\
\text { Sig. (2- } \\
\text { tailed) } \\
\mathrm{N}\end{array}$ & $\begin{array}{r}.238 \\
.206 \\
30\end{array}$ & 30 & $\begin{array}{r}.081 \\
.669 \\
30\end{array}$ \\
\hline $\mathrm{X} 2$ & $\begin{array}{l}\text { Pearson } \\
\text { Correlation } \\
\text { Sig. (2- } \\
\text { tailed) } \\
\mathrm{N}\end{array}$ & $\begin{array}{r}.026 \\
.892 \\
30\end{array}$ & $\begin{array}{r}.081 \\
.669 \\
30\end{array}$ & 1 \\
\hline
\end{tabular}

b. Uji t, uji f, Determinasi

1) Uji t

Untuk mengetahui kebenaran dari perhitungan korelasi, maka dilakukan pengujian hipopenelitian. Perumusan hipopenelitian yang akan diuji diberi simbol Ho, sedangkan hipopenelitian alternatif diberikan simbol Ha.

Tabel-14. Model Summary(b)

\begin{tabular}{|l|c|c|c|}
\hline Model & R & R Square & \multicolumn{2}{|c|}{$\begin{array}{c}\text { Adjusted R } \\
\text { Square }\end{array}$} \\
\hline 1 & $.637^{\mathrm{a}}$ & .406 & .362 \\
\hline
\end{tabular}


dengan melihat Tabel-13, angka $R$ square adalah $0,637 . R$ square bisa disebut koefisien determinasi, dengan nilai koefisien determinasi dari persamaan regresi sebesar 0,406 dengan nilai koefisien determinasi yang disesuaikan sebesar 0.362 karena persamaan regresi menggunakan lebih dari satu variable, maka koefisien determinasi yang baik untuk digunakan dalam menjelaskan persamaan dengan koefisien determinasi yang disesuaikan, yang dalam hal ini berarti 63,70 $\%$ variabel kepuasan pelanggan dijelaskan oleh variabel kualitas produk. Sedangkan sisanya 100 $\%-63,70 \%=36,30 \%)$ dijelaskan oleh sebab-sebab yang lain. Rsquare berkisar pada angka 0 sampai 1, dengan catatan semakin kecil angka $\mathrm{R}$ square, semakin lemah hubungan kedua variabel.

\section{2) $\mathbf{U j i} \mathbf{F}$}

Untuk melihat sejauhmana hubungan variabel bebas kualitas produk dan harga dengan variabel terikat kepuasan pelanggan, maka dilakukan analisa uji $\mathrm{F}$ dengan program SPSS.

Tabel-15. Anova ${ }^{\mathbf{b}}$

\begin{tabular}{|ll|r|r|r|c|c|}
\hline Model & & $\begin{array}{c}\text { Sum of } \\
\text { Square }\end{array}$ & df & $\begin{array}{c}\text { Mean } \\
\text { Square }\end{array}$ & F & Sig. \\
\hline 1 & $\begin{array}{l}\text { Regression } \\
\text { Residual } \\
\text { Total }\end{array}$ & 202.628 & 2 & 101.314 & 9.240 & $.001^{\mathrm{a}}$ \\
& 296.039 & 27 & 10.964 & & \\
\hline
\end{tabular}

a. Predictors: (Constant), X2, X1

b. Dependent Variable: Y

\section{a) Berdasarkan Nilai Signifikan} (Sig.) dari Output Anova.

Berdasarkan tabel output di atas, diketahui nilai Sig. adalah sebesar 0.00. Karena nilai sig. $0.00<0.05$, maka sesuai dengan dasar pengambilan dalam uji $\mathrm{F}$ dapat disimpulkan bahwa hipotesis diterima atau dengan kata lain kualitas produk $\left(\mathrm{X}_{1}\right)$ dan peluang pasar $\left(\mathrm{X}_{2}\right)$ secara simultan berpengaruh terhadap kualitas pelanggan (Y).

b) Berdasarkan Perbandingan Nilai $\mathbf{F}_{\text {hitung }}$ dengan $\mathbf{F}_{\text {tabel }}$.

Dari uji Anova atau $\mathrm{F}_{\text {test }}$ (lihat Tabel-14), di dapat $F_{\text {hitung }}$ sebesar 9.240. > $\mathrm{F}_{\text {tabel }} 3.33$. Dengan kondisi di mana nilai $F_{\text {hitung }}$ lebih besar daripada $F_{\text {tabel dan nilai }}$ signifikan yang lebih kecil daripada alpha (0,05), maka kesimpulan 
hipotesis diterima atau dengan kata lain kualitas produk $\left(\mathrm{X}_{1}\right)$ dan peluang pasar $\left(\mathrm{X}_{2}\right)$ secara simultan berpengaruh terhadap kualitas pelanggan (Y).

\section{Kesimpulan}

Hubungan kualitas produk menunjukkan adanya hubungan yang positif dan signifikan antara peluang pasar, besar hubungan antara variabel kualitas produk dan variabel kepuasan pelanggan yang dihitung dengan koefisien korelasi adalah 0,238 dengan nilai signifikan sebesar 0,103 .

Hubungan antara variabel peluang pasar dengan variabel kepuasan pelanggan yang dihitung dengan koefisien korelasi adalah 0,26 dengan nilai signifikan sebesar 0,446 terdapat hubungan yang positif.

Hubungan Kualitas produk hubungan / keeratannya dengan variabel kepuasan pelanggan sangat kuat / korelasi sangat erat $(0,238>0,103)$. Variabel peluang pasar hubungan / keeratannya dengan variabel kepuasan pelanggan rendah / korelasi rendah $(0,26<0,446)$.

\section{Saran}

Wastu Wisata harus terus memperhatikan kualitas produk maupun peluang pasar yang ditawarkan dalam upaya meningkatkan kepuasan pelanggan.
Dimana produk wisata saat ini banyak penawaran diberbagai online penawaran produk Wastu Wisata harus lebih digiatkan dan paket perjalanan dikemas secara menarik.

Wastu Wisata harus senantiasa meningkatkan peluang pasar dalam memasarkan produk wisata dan upaya mengajak para pelanggan untuk menggunakan produk wisata dari Wastu Wisata.

Dalam hal ini kepuasan pelanggan harus diprioritaskan dalam upaya penggunaan produk wisata dengan memberikan produk yang memuaskan.

\section{DAFTAR PUSTAKA}

Abdul Majid, Suharto. 2009, Customer Service dalam Bisnis Jasa Transportasi, RajaGrafindo Persada Jakarta.

A.J. Mulyadi. 2009, Kepariwisataan dan Perjalanan, Raja Grafindo Persada, Jakarta.

Alma, Buchari. 1996, Manajemen Pemasaran dan Pemasaran Jasa, penerbit Alfabeta, Bandung.

Arikunto, Suharsimi. 2002. Metodologi Penelitian. Penerbit PT. Rineka Cipta, Jakarta. 
Budi Santosa, et. all. 2005, Analisis Statistik dengan Microsoft Excel \& SPSS, Penerbit ANDI, Yogyakarta.

Doganis, Rigas. 1995, Flying off Course, The Economics of International Airlines, Rautledge, London \& New York.

Kotler, Philip. 1995, Manajemen Pemasaran, jilid 1, Penerbit Karisma Publisihing, Jakarta.

Lupiyoadi, Rambat. 2001. Manajemen Pemasaran Jasa, Teori dan Praktek. Edisi Pertama. Jakarta: Salemba Empat. 